\title{
Корисні копалини
}

doi: https://doi.org/10.15407/gpimo2019.01.074

\author{
Ю.И. Иноземцев, А.А. Парышев, \\ 3.В. Красножина, Н.А. Маслаков \\ ГНУ «Центр проблем морской геологии, экологии \\ и осадочного рудообразования» НАН Украины, Киев
}

\section{МАГНЕТИТ ИЗ ПРИБРЕЖНО-МОРСКИХ РОССЫПЕЙ ЧЕРНОГО И АЗОВСКОГО МОРЕЙ}

В статье приведена информация о характере распределения и минеральном составе современных прибрежно-морских россыпей Черного и Азовского морей. Выделены следующие основные типы россыпей: ильменит-рутил-цирконовые, иногда с примесью монацита; магнетит-титаномагнетитовые с иирконом и ильменитом; гранатово-магнетитовые и магнетитовые. Приведены результаты минералого-геохимических исследований магнетитов из основных россыпей и россыпепроявлений.

Ключевые слова: Черное, Азовское моря, прибрежно-морские россыпи, магнетит.

\section{Введение}

Бассейн Черного моря - интересный и перспективный район развития морских россыпей. Своеобразие бассейна Черного моря, его гидродинамического режима и геологической истории, различия литологического и петрографического состава осадочных и изверженных пород окружающих море регионов, наличие многочисленных речных артерий - все это определяет своеобразие развития россыпей на границе суши и моря, разнообразие минерального состава (рис. 1).

Для современных россыпей Черного и Азовского морей характерна относительная ограниченность комплекса полезных минералов, среди которых преобладают ильменит, рутил, циркон, реже монацит, а также магнетит, своего рода черноморский космополит, который встречается повсеместно. Остальные рудные минералы, в частности, такие как алмаз, золото, монацит, хромит промышленного значения пока не имеют, хотя и встречаются в виде единичных находок.

(С Ю.И. ИНОЗЕМЦЕВ, А.А. ПАРЫШЕВ, З.В. КРАСНОЖИНА,

Н.А. МАСЛАКОВ, 2019 
По минеральному составу можно выделить два основных типа россыпей Черного моря: 1) ильменит-рутил-цирконовые, иногда с примесью монацита (Северное Приазовье, северо-западная часть черноморского шельфа - о. Джарылгач, Днепровско-Бугский лиман); 2) магнетит-титаномагнетитовые с цирконом и ильменитом (Южная Болгария, Турция к западу от Босфора), гранатово-магнетитовые (район Таманского побережья - Анапа - оз. Соленое - Железный Рог), магнетитовые (Грузия, Турция восточнее Босфора близ Дершиле).

Ильменит-рутил-цирконовые россыпи приурочены преимущественно к северной части Черного и Азовского морей, что обусловлено формированием их за счет размыва Украинского кристаллического щита, сложенного, главным образом, породами кислого состава.

Черноморские россыпи с преобладанием магнетита в тяжелой фракции сформировались за счет размыва более молодых, чаще всего мезо-кайнозойских толщ, слагающих горные сооружения Кавказа, Балкан, Крыма. В разрезе этих альпийских сооружений существенную роль играют вулканиты, основные и кислые породы. На болгарском, кавказском и турецком побережьях магнетит накапливается как за счет прямого размыва рудовмещающих толщ морем, так и за счет выноса рудного материала сравнительно короткими речными артериями. Несколько особняком стоит в ряду прибрежно-морских россыпей магнетитогранатовая залежь близ Соленого озера у Анапы, где она совершенно обособлена от других рудопроявлений черноморского побережья Кавказа и, несомненно, связана с перемывом аллювиальных отложений палео-Кубани.

Ниже приводится более подробное описание основных россыпей Черного моря, сложенных преимушественно магнетитом.

Болгарское побережье. Наиболее значительные россыпепроявления магнетита приурочены к прибрежным пескам Несебырского и Бургасского заливов Южной Болгарии.

Начало их исследования относится к 1912 г. В последующем их изучением занимались В.И. Цветкова-Голева [16], Е.Ф. Шнюков, Ю.В. Соболевский, А.В. Григорьев [20], П.С. Димитров, 3.Т. Новикова [6] и др. По данным этих исследований, обобщенных Е.Ф. Шнюковым [19], магнетитовые пляжевые пески простираются на 50 км от г. Несебр до г. Созопол.

Магнетит приурочен к песчаным отложениям аккумулятивных и аккумулятивно-абразионных участков берега. Содержание тяжелой фракции, где преобладает магнетит, в пляжных песках достигает 50 \% (Георгиев, 1975), с глубиной моря уменьшается и глубже 15 м не превышает $1-3 \%$. В пляжевых отложениях магнетит слагает тонкие линзы и слои толщиной от миллиметра до нескольких сантиметров. Самые значительные концентрации магнетита в мелкопесчаных осадках пляжей установлены севернее и восточнее г. Бургас.

Вместе с магнетитом встречаются ильменит, хромит, циркон, рутил, гематит, лейкоксен, пироксены, гранаты, амфиболы, сфен, ставролит, эпидот и др. [16].

По мнению В.И. Цветковой-Голевой (1975), источником магнетита и других минералов тяжелой фракции чаще всего являются меловые и другие вулканиты Бургасского синклинория и разновозрастные породы Странджанского антиклинория. Совместные украинско-болгарские исследования, выполненные на судне «Геохимик» (Шнюков, Асланов, Хрисчев, 1976), показали важную роль аллювиальных отложений мелководной зоны шельфа как промежуточно- 


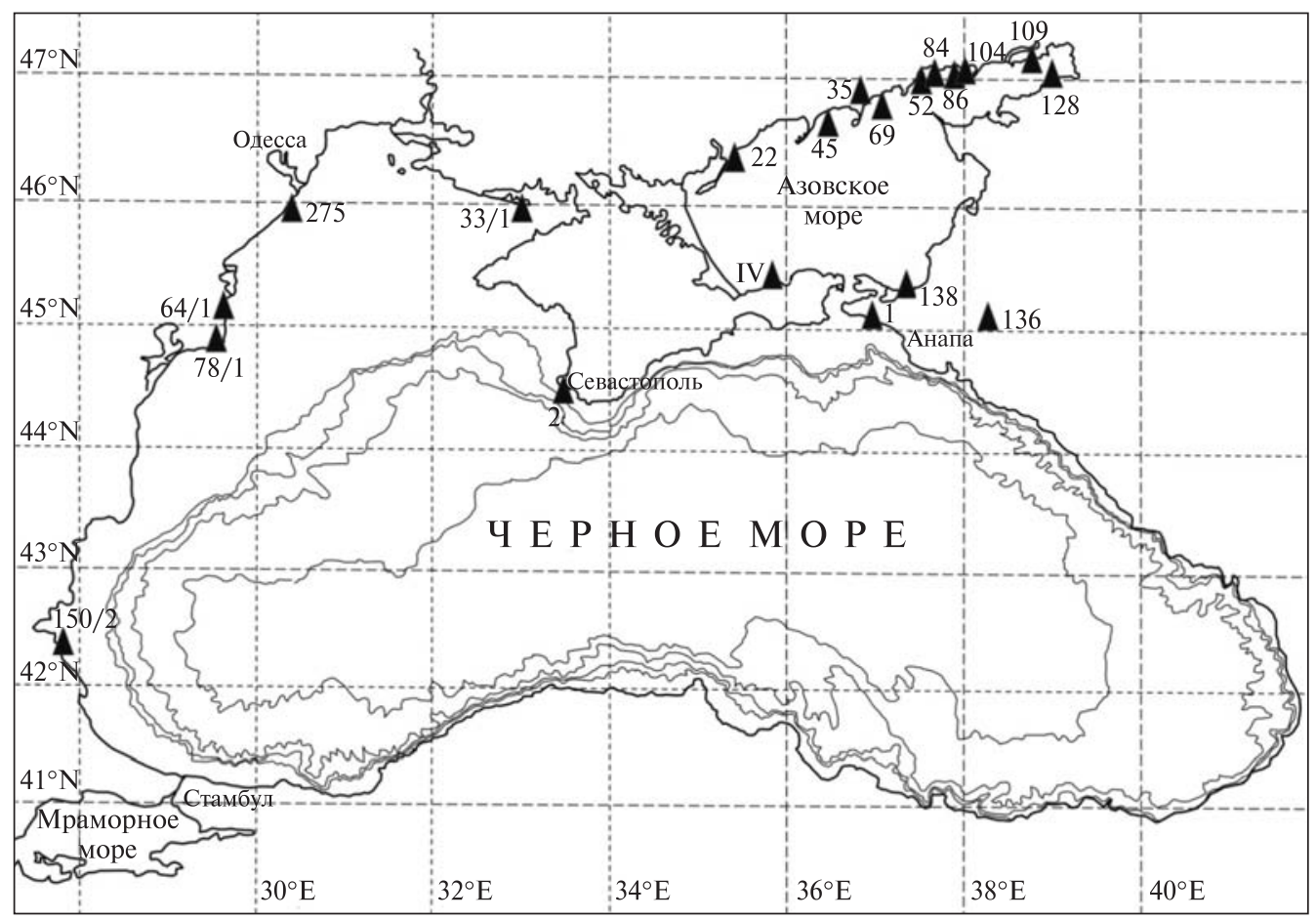

Puc. 1. Карта-схема отбора образцов из прибрежно-морских россыпей Азово-Черноморского бассейна

го коллектора магнетита и их последующий перемыв в древнечерноморский момент четвертичной истории Черного моря. В разрезе отложений БургасскоНесебырского района фиксируются два слоя аллювиальных отложений, за счет размыва которых и формируются рудные россыпи.

Магнетитовые россыпи Болгарии представляют собой пляжевые образования мощностью 0,4-0,5 м, реже до 1 м и шириной до 50-100 м. Среднее содержание концентрата магнетита в пляжевых отложениях Бургасского залива сос-

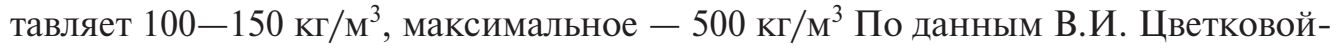
Голевой (1974), на ряде участков побережья (с. Сафарово и м. Ахелой) магнетит является наиболее распространенным минералом, где его содержание колеблется от 1444 кг/м³ на пляже в районе с. Сарафово и 1972 кг/м³ в районе м. Ахелой.

На некоторых участках (гг. Поморие и Созопол) содержание магнетита меньше $1 \mathrm{kг} / \mathrm{M}^{3}$. Из других минералов тяжелой фракции наиболее высокое содержание (11-16 \%) характерно для ильменита, а также хромита (6,9-12,9 \%) (южнее Бургаса). Кроме этих основных минералов в тяжелой фракции содержатся пироксен, циркон, сфен, гранат, апатит, монацит, хромшпинелиды, эпидот, пирит. Пироксены (гиперстен, диопсид) севернее г. Поморие составляют 70-90 \% тяжелой фракции. Содержание тяжелой фракции в прибрежных осадках уменьшается с глубиной и на отметках более 10 м не превышает 2-3\%.

Россыпепроявления Болгарии образовались за счет размыва протерозойских и мезозойских осадочно-вулканогенных пород южной питающей провинции, охватывающей площадь, ограниченную на севере Забалканским глубин- 
ным разломом (широта устья р. Хаджийска), на юге устьем р. Резовска (турецкая граница) и на западе горным хребтом Странджа. Далее к югу отмечается полоса бедного оруденения и лишь близ Босфора (Турция, селения Кифталан и Шиле) вновь появляются богатые россыпепроявления магнетита.

Россыпи Грузии. Впервые магнетитовые россыпи Грузии были описаны К.Н. Габуния в 1933 г. [3]. В дальнейшем они были детально изучены и разведаны в 1964 г. Ф.Т. Парцвания и Н.Т. Оситашвили, а в 1977 г. К.И. Джанжгавой и Г.Е. Яшвили [5]. Установлено, что между устьями рек Чорох и Бзыбь запасы магнетита в пляжевых отложениях достигают 40-45 млн тонн. Наибольший интерес представляет Урекский участок между реками Супса и Натанеби длиной около 12 км. Кобулетский участок между реками Натанеби и Кинтриши длиной 11 км значительно беднее. На Урекском участке магнетит накапливается преимущественно в волноприбойной зоне современного пляжа и береговых валах, а также в отложениях более высоких (до 2-4 м) нимфейской и новочерноморской террас. Содержание магнетита в этих отложениях достигает $10-15 \%$, Повышенные содержания магнетита отмечаются на подводном склоне между реками Супса и Натанеби на глубинах 7-10 м, где К.И. Джанжгава и Г.Е. Яшвили предлагали заложить два экспериментальных карьера по добыче магнетитовых песков.

Прибрежно-морские россыпи Грузии формируются за счет выносов аллювия реками Рион, Супса, Натанеби, Ингури, Кодори, Бзыбь, Галидзга и др. Основным источником магнетита считаются андезиты и андезит-базальты Аджаро-Имеретинского хребта (Т.А. Твалчрелидзе [14]). Кроме магнетита в песках пляжа обнаружены титаномагнетит, эпидот, амфиболы, оливин, ильменит, хлорит, сфен, рутил, гранат, апатит, слюды, пироксены.

\section{Минералогические особенности магнетитов}

В ходе изучения путей поступления магнетита в акваторию Черного моря проводилось минералогическое изучение и описание магнетита, привносимого реками Дунай, Днестр, Кубань, а также из коренного берега в районе г. Мариуполь (у с. Широкино).

Магнетит из прибрежно-морских россыпей Болгарского шельфа встречается в виде зерен октаэдрической и ромбододекаэдрической формы и их обломков размером до 0,5-0,7 мм, в основном 0,15-0,22 мм. Черный, иногда с синеватой побежалостью, блеск металлический. Магнетиты Поморие слабоокатанные и неокатанные, доминируют грани $\{111\}$ и $\{110\}$. Для магнетита Бургасского залива характерны окатанные зерна, часто с красно-бурыми налетами гематита, реже кристаллы - неокатанные. Грани кристаллов в основном шероховатые, а у совершенно неокатанных разностей - ровные, гладкие, блестящие. По данным В.И. Цветковой-Голевой (1975), поступление магнетита происходит из меловых пород и вулканитов Бургасского синклинория, а также разновозрастных пород Странджанского антиклинория.

Изученный магнетит мелководного шельфа Черного моря южного берега Крыма характеризуется присутствием неокатанных зерен и их обломков размером до 0,25 мм. Это свежие, неизмененные магнетиты черного цвета, с синеватой побежалостью и металлическим блеском. Источником их поступления в 
Черное море, по-видимому, являются магматические и вулканические породы Горного Крыма.

Минералогический анализ магнетита прибрежных отложений Азовского моря показывает наличие в составе тяжелых фракций неокатанных и слабоокатанных обломков зерен темно-серого и черного цвета, часто измененного и покрытого налетами гематита красного, красно-бурого цвета, который при разламывании сохраняет внутри черную окраску и магнитные свойства. Кристаллы магнетита с хорошо выраженной октаэдрической формой относительно редки - до 1-2\%. Размер зерен иногда достигает 0,5 мм, в основном составляет 0,15-0,20 мм. Встречаются магнетиты, имеющие мелкокристаллическое, агрегатное строение.

Магнетит установлен среди основных и ультраосновных пород Западного Приазовья как ведущий акцессорный рудный минерал [11]. Нами изучен магнетит из коренного берега у с. Широкино. Он представлен очень мелкими угловатыми обломками зерен размером до 0,1-0,15 мм, сильно магнитный. Зерна октаэдрического облика не характерны. Изредка обломки зерен покрыты красноватым налетом.

Детальные магнитно-минералогические исследования пляжевых песков Грузии (Аджария) и Крыма (пос. Партенит) выполнили Ю.А. Курников и др. [10]. Установлено, что в пляжевых песках магнетит составляет до 10 \% тяжелой фракции. Главными минералами являются пироксен и магнетит. В песках пос. Партенит магнетит выявлен в количестве $3 \%$, при основном минерале пироксене - $70 \%$.

Магнетит, привносимый р. Дунай, характеризуется преобладанием мелких слабоокатанных зерен размером до 0,25 мм, в основной массе - 0,1-0,15 мм. Черный, с сильным металлическим блеском и слегка шероховатой поверхностью. Отдельные зерна с красно-бурым налетом, черные внутри. Грани октаэдра слегка округлены в процессе окатывания. Магнетит, поступающий в Черное море в составе аллювия р. Днестр, несколько крупнее - до 0,3 мм, в основном - 0,15-0,2 мм. Это чистые слабоокатанные зерна черного цвета, практически без налета, обладающие металлическим блеском. Магнетит р. Кубань представлен слабоокатанными зернами черного и темно-серого цвета размером до 0,3 мм, в основной массе - 0,15-0,2 мм. Для некоторых зерен черного цвета характерна темно-синяя побежалость. Встречаются измененные красноватобурые магнетиты, при раскалывании внутри черные.

\section{Геохимические особенности магнетита из россыпей и россыпепроявлений Азово-Черноморского бассейна}

Магнетит довольно интересен с геохимической точки зрения. Он обычно содержит в виде изоморфной примеси ряд химических элементов $\mathrm{Cr}, \mathrm{V}, \mathrm{Ti}, \mathrm{Ni}, \mathrm{Co}, \mathrm{Mn}$ и др.

Теоретически по химическому составу магнетит содержит $\mathrm{FeO}-31 \%, \mathrm{Fe}_{2} \mathrm{O}_{3}-$ $69 \%$. Однако, для него характерна примесь до нескольких процентов $\mathrm{TiO}_{2}$ (титаномагнетит), $\mathrm{Cr}_{2} \mathrm{O}_{3}$ (хромомагнетит). Изредка встречаются разности, богатые $\mathrm{MgO}$ (до $10 \%), \mathrm{Al}_{2} \mathrm{O}_{3}(15 \%)$ и др. [2].

Ниже приведены результаты химического анализа ультраосновных пород Октябрьского массива Восточного Приазовья, в которых содержание $\mathrm{TiO}_{2}$ со- 


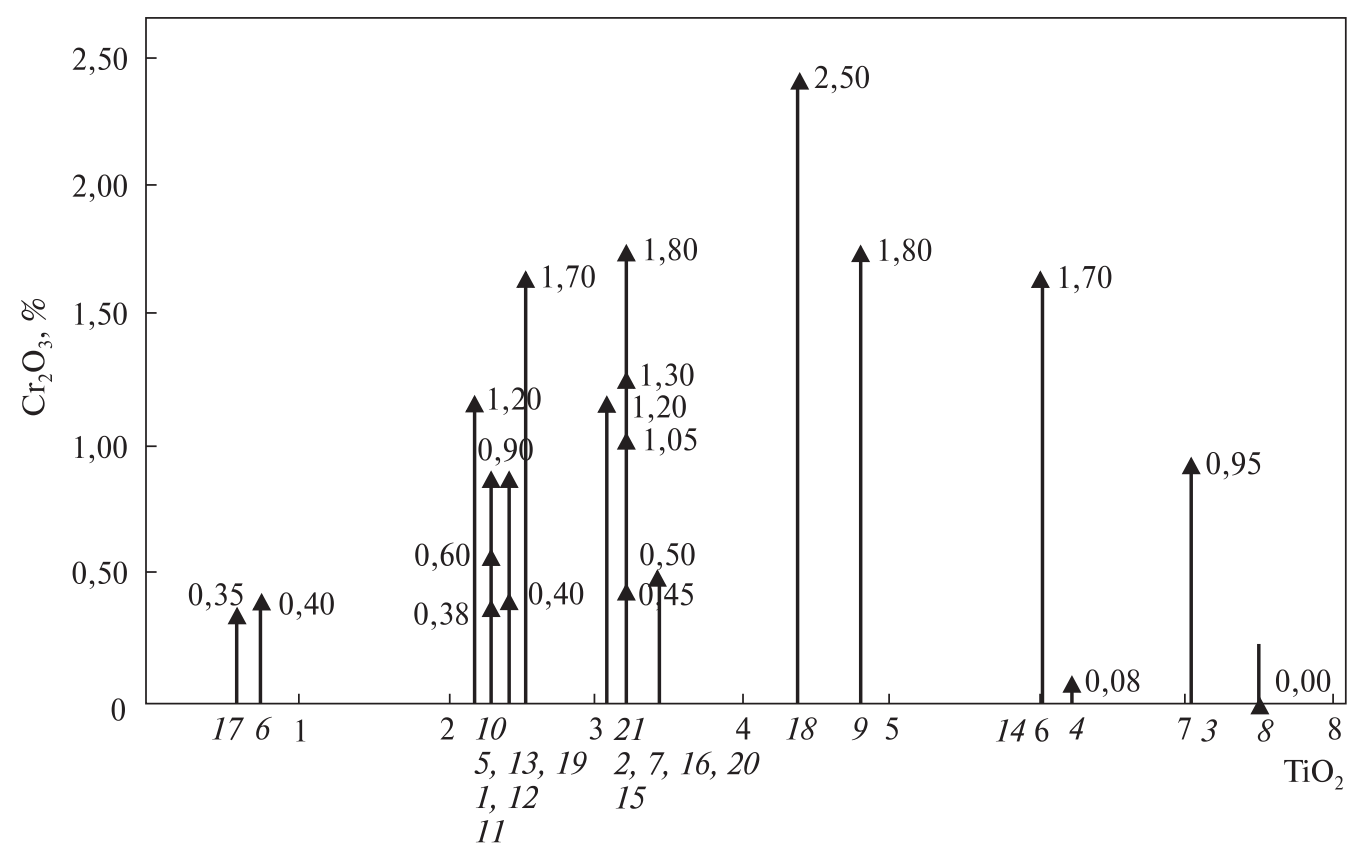

Puc. 2. Корреляция содержания $\mathrm{Cr}_{2} \mathrm{O}_{3}$ и $\mathrm{TiO}_{2}$ в магнетитах из прибрежно-морских россыпей Черного и Азовского морей

Таблица 1. Химический состав магнетита (\%), по [8]

\begin{tabular}{|c|c|c|c|c|}
\hline Компоненты & $\begin{array}{c}84 \text { Белосарайская } \\
\text { коса } 1\end{array}$ & $\begin{array}{c}1 \text { Октябрьский } \\
\text { массив }^{2}\end{array}$ & $\begin{array}{c}2 \text { Октябрьский } \\
\text { массив } 3\end{array}$ & $\begin{array}{c}5 \text { Салтычанский } \\
\text { массив } 3\end{array}$ \\
\hline $\mathrm{SiO}_{2}$ & 0,69 & 0,65 & 1,58 & 0,82 \\
\hline $\mathrm{TiO}_{2}$ & 4,90 & 1,76 & 4,86 & 0,35 \\
\hline $\mathrm{Al}_{2} \mathrm{O}_{3}$ & 1,20 & 0,07 & 1,60 & Сл. \\
\hline $\mathrm{C}_{\Gamma_{2}} \mathrm{O}_{3}$ & 5,80 & - & Сл. & - \\
\hline $\mathrm{Fe}_{2} \mathrm{O}_{3}$ & 61,21 & 67,94 & 61,31 & 66,51 \\
\hline $\mathrm{FeO}$ & 23,71 & 26,95 & 30,63 & 29,28 \\
\hline $\mathrm{MnO}$ & 0,28 & 2,19 & 0,12 & 0,06 \\
\hline $\mathrm{MgO}$ & 0,50 & 0,15 & - & - \\
\hline $\mathrm{CaO}$ & 0,33 & 0,30 & 0,20 & 1,30 \\
\hline $\mathrm{Na}_{2} \mathrm{O}$ & 0,33 & - & - & - \\
\hline $\mathrm{K}_{2} \mathrm{O}$ & Сл. & - & - & - \\
\hline $\mathrm{P}_{2} \mathrm{O}_{5}$ & 0,32 & - & 0,05 & 0,15 \\
\hline $\mathrm{H}_{2} \mathrm{O}$ & 0,12 & - & 0,02 & 0,20 \\
\hline П.п.п. & 0,20 & - & - & - \\
\hline Сумма & 99,59 & 100,01 & 100,37 & 98,67 \\
\hline
\end{tabular}

П ри м е ч ан и е : ${ }^{1}$ Ю.И. Иноземцев, ${ }^{2}$ Н.А. Елисеев и др. $(1965),{ }^{3}$ Ю.Ю. Юрк, Е.Я. Марченко, А.И. Чайка (1973).

ставляет 4,86 \%, и магнетита из россыпей Белосарайской косы (к югу от г. Мариуполь) с содержанием $\mathrm{TiO}_{2} 4,90 \%$, что может быть доказательством источника магнетита и других акцессорных минералов (ильменит) из упомянутого кристаллического массива (табл. 1). Из других россыпепроявлений с наиболее высоким содержанием характеризуется титаномагнетит из песков юго-западно- 
Таблица 2. Содержание примесей окислов химических элементов в магнетите из россыпей Черного и Азовского морей (\%)

\begin{tabular}{|r|c|c|c|c|c|c|c|c|c|}
\hline $\begin{array}{r}\text { № табл. } \\
\text { и рис. }\end{array}$ & $\begin{array}{c}\text { № на карте } \\
\text { (рис. 1) }\end{array}$ & $\mathrm{SiO}_{2}$ & $\mathrm{Al}_{2} \mathrm{O}_{3}$ & $\mathrm{MgO}$ & $\mathrm{CaO}$ & $\mathrm{MnO}$ & $\mathrm{TiO}_{2}$ & $\mathrm{~V}_{2} \mathrm{O}_{5}$ & $\mathrm{Cr}_{2} \mathrm{O}_{3}$ \\
\hline 1 & $64 / 1$ & 0,42 & 0,85 & 0,70 & 0,10 & 0,15 & 2,40 & 0,23 & 0,90 \\
2 & $\mathrm{IV}$ & 0,55 & 2,40 & 1,30 & 0,15 & 0,52 & 3,20 & 0,30 & 1,30 \\
3 & 84 & 0,45 & 1,05 & 0,75 & 0,17 & 0,57 & 7,00 & 0,08 & 0,95 \\
4 & 275 & 0,50 & 1,10 & 0,90 & 0,15 & 0,50 & 6,20 & 0,20 & 0,08 \\
5 & $78 / 1$ & 0,35 & 1,0 & 0,70 & 0,25 & 0,15 & 4,30 & 0,13 & 0,60 \\
6 & $33 / 1$ & 0,25 & 0,80 & 0,35 & 0,17 & 0,05 & 0,75 & 0,08 & 0,40 \\
7 & 1 & 0,70 & 1,4 & 1,3 & 0,52 & 0,70 & 3,20 & 0,22 & 1,80 \\
8 & 2 & 0,30 & 0,30 & 0,25 & 0,40 & 0,65 & 7,50 & 1,40 & - \\
9 & 22 & 0,35 & 1,2 & 0,8 & 0,20 & 0,55 & 4,8 & 0,15 & 1,8 \\
10 & 35 & 0,75 & 1,15 & 0,65 & 0,25 & 0,20 & 2,2 & 0,18 & 1,2 \\
11 & 45 & 0,45 & 1,2 & 0,75 & 0,35 & 0,28 & 2,5 & 0,17 & 1,7 \\
12 & 52 & 0,55 & 1,0 & 0,8 & 0,45 & 0,30 & 2,4 & 0,18 & 0,40 \\
13 & 69 & 0,40 & 1,2 & 0,6 & 0,10 & 0,35 & 2,3 & 0,18 & 0,38 \\
14 & 84 & 0,38 & 3,5 & 1,0 & 0,30 & 0,70 & 6,0 & 0,14 & 1,7 \\
15 & 86 & 0,40 & 1,15 & 0,55 & 0,40 & 0,40 & 3,4 & 0,21 & 0,5 \\
16 & 104 & $\sim 1,8$ & 1,2 & 0,60 & 0,58 & 0,40 & 3,2 & 0,18 & 1,05 \\
17 & 109 & 0,65 & 0,5 & 0,50 & 0,15 & 0,52 & 0,6 & 0,02 & 0,35 \\
18 & 128 & 0,58 & 1,25 & 1,0 & 0,45 & 0,55 & 4,4 & 0,17 & 2,5 \\
19 & 136 & 0,47 & 1,3 & 0,70 & 0,30 & 0,42 & 2,3 & 0,10 & 0,9 \\
20 & $150 / 2$ & 0,40 & $\sim 2$ & 1,0 & 0,28 & 0,70 & 3,2 & 0,25 & 0,45 \\
21 & 138 & 0,45 & 1,3 & 0,85 & 0,45 & 0,65 & 3,1 & 0,16 & 1,2 \\
& & & & & & & & & \\
\hline
\end{tabular}

Аналитик С.А. Козак.

П р и м е ч н и е: 1 (64/1), р. Дунай; 2 (IV), Юг Азовского моря, Арабатский залив; 3 (84), Белосарайская коса; 4 (275), Днестровский лиман; 5 (78/1), р. Дунай; 6 (33/1), о. Джарылгач; 7 (1), оз. Соленое; 8 (2), Крым; 9 (22), Коса Федотова; 10 (35), Бердянский залив; 11 (45), Коса Обиточная; 12 (52), Бердянский залив; 13 (69), Белосарайский залив, район Новопетровки; 14 (84), Белосарайская коса; 15 (86), Северный берег Таганрогского залива, район п. Широкое; 16 (104), Северный берег Таганрогского залива, район п. Широкое; 17 (109), Северный берег Таганрогского залива, корневая часть косы Беглицкой; 18 (128), Стефанидин Дар; 19 (136), р. Кубань; 20 (150/2), Бургас; 21 (138), Темрюкский залив.

го Крыма (пос. Любимовка), где содержание $\mathrm{TiO}_{2}-7,5$ \%. Магнетит из других россыпей и проявлений содержится в пределах от 0,6 до 7,5 \% (табл. 2).

Окись хрома $\mathrm{Cr}_{2} \mathrm{O}_{3}$ из прибрежно-морских россыпей содержится в диапазоне от $0,08 \%$ до $1,8 \%$. Обычно повышенное содержание $\mathrm{Cr}_{2} \mathrm{O}_{3}$ коррелируется с повышенным содержанием $\mathrm{TiO}_{2}$, за исключением магнетитов из участка Днестровского лимана $\left(\mathrm{Cr}_{2} \mathrm{O}_{3}-0,08 \%\right.$ при содержании $\left.\mathrm{TiO}_{2}-6,20 \%\right)$ и югозападного крымского побережья где при довольно высоком содержании $\mathrm{TiO}_{2}$ (7,50 \%) $\mathrm{Cr}_{2} \mathrm{O}_{3}$ не установлен вовсе (см. табл. 2, рис. 2).

Поскольку $\mathrm{TiO}_{2}$ является существенной химической примесью в магнетите (титаномагнетите) мы провели корреляцию содержания $\mathrm{TiO}_{2}$ и других значимых соединений (оксидов) в магнетитах (табл. 2).

Окись $\mathrm{Mg}$ установлена в количестве от 0,25 и 0,35 \% (Крымский участок) и до 1,3\% - юг Азовского моря. В преимущественной части проб магнетита содержание $\mathrm{MgO}$ колеблется от 0,50 до 1,0\% (рис. 3). 


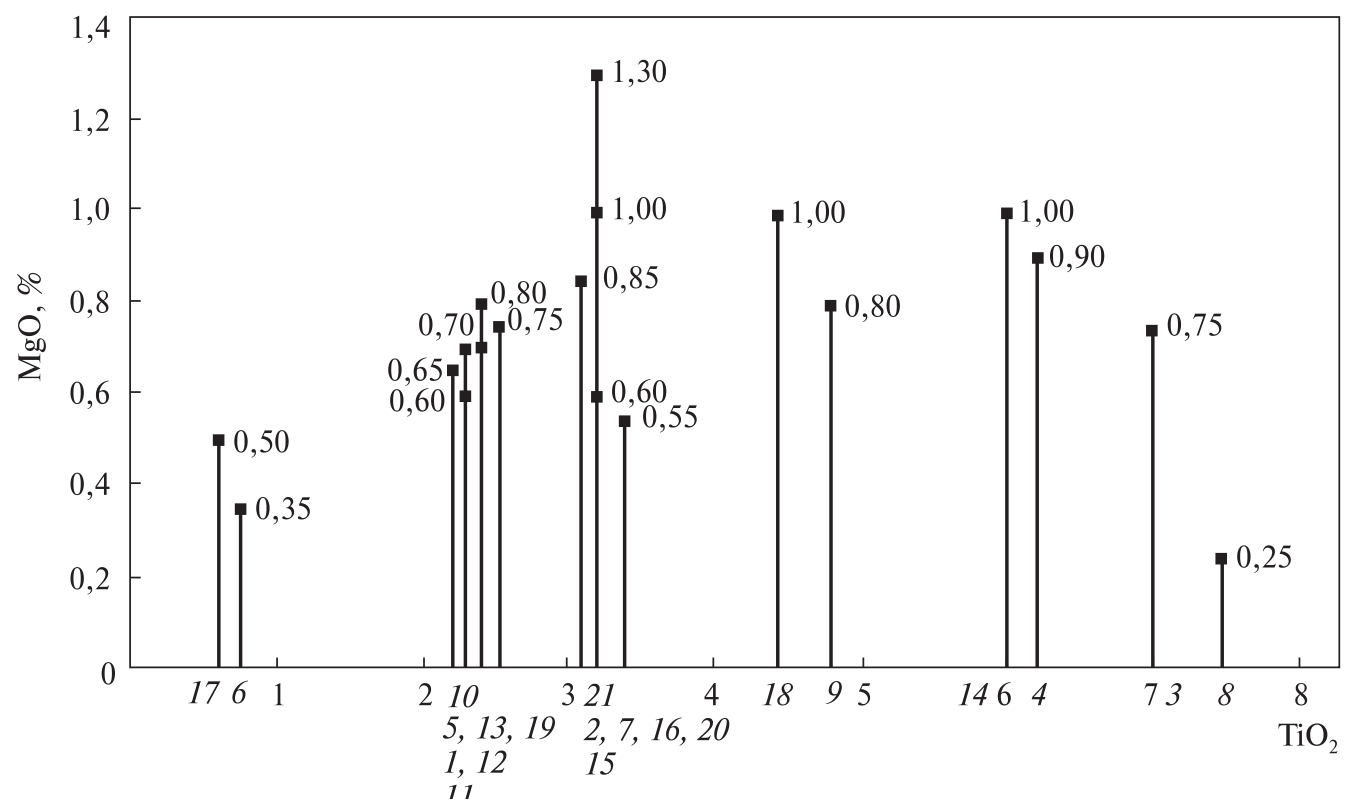

Puc. 3. Корреляция содержания $\mathrm{MgO}$ и $\mathrm{TiO}_{2}$ в магнетитах

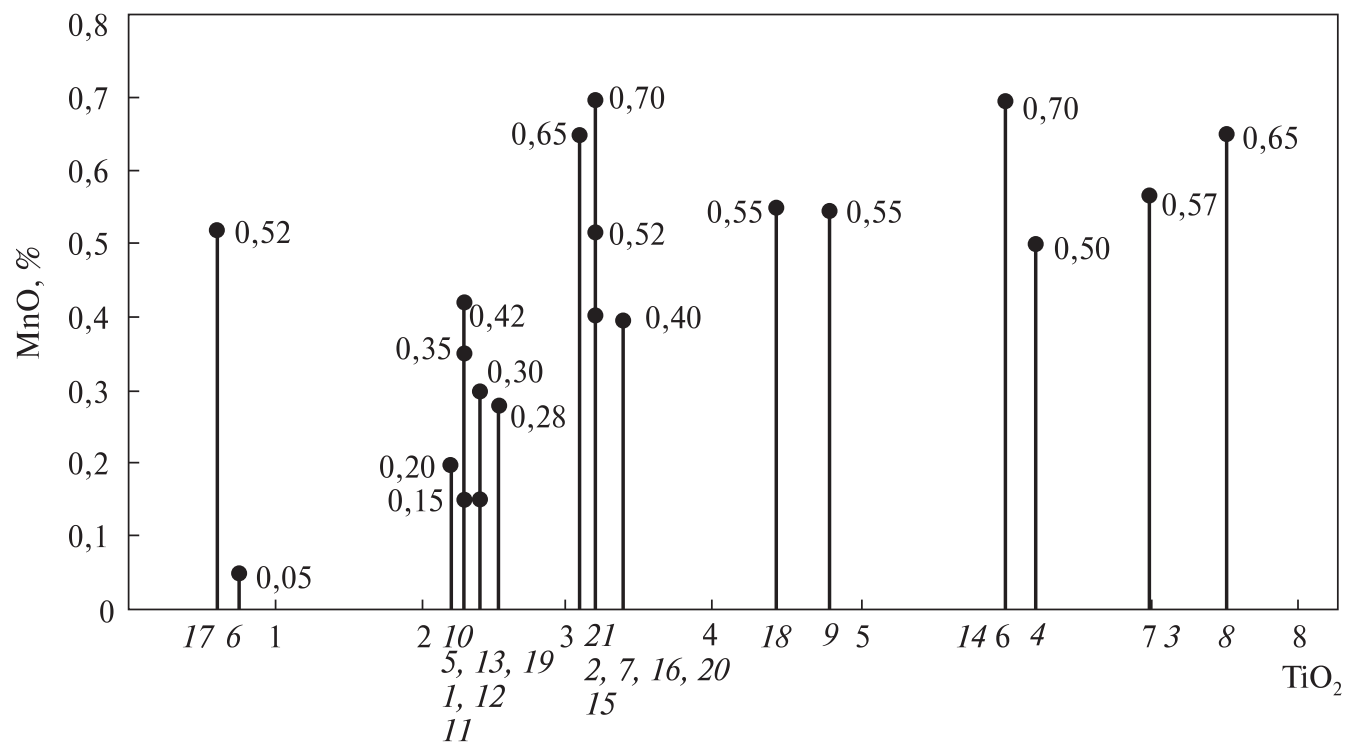

Puc. 4. Корреляция содержания $\mathrm{MnO}$ и $\mathrm{TiO}_{2}$ в магнетитах

Окись Мn содержится в количестве от 0,05 (о. Джарылгач) до 0,70 \% (оз. Соленое, Днестровский лиман, Бургас). При сопоставлении содержания $\mathrm{MnO}$ с $\mathrm{TiO}_{2}$ можно выделить два участка (рис. 4) с содержанием $\mathrm{MnO}$ от 0,035 \%- 0,70 \% и $\mathrm{TiO}_{2}$ (от $0,15 \%$ - Дунай и до $0,70 \%$ Бургас, Болгария) и второй участок с содержанием от 0,5-0,70 \% напротив пос. Любимовка (Крым).

$\mathrm{V}_{2} \mathrm{O}_{5}$ содержится в незначительных количествах от 0,2-0,08 \% (Таганрогский залив, коса Беглицкая) до 1,40 \% (Крымское побережье), что выглядит ураганным на фоне $0,10-0,30 \%$ для основного количества магнетитов Азово-Черноморского бассейна (рис. 5). 


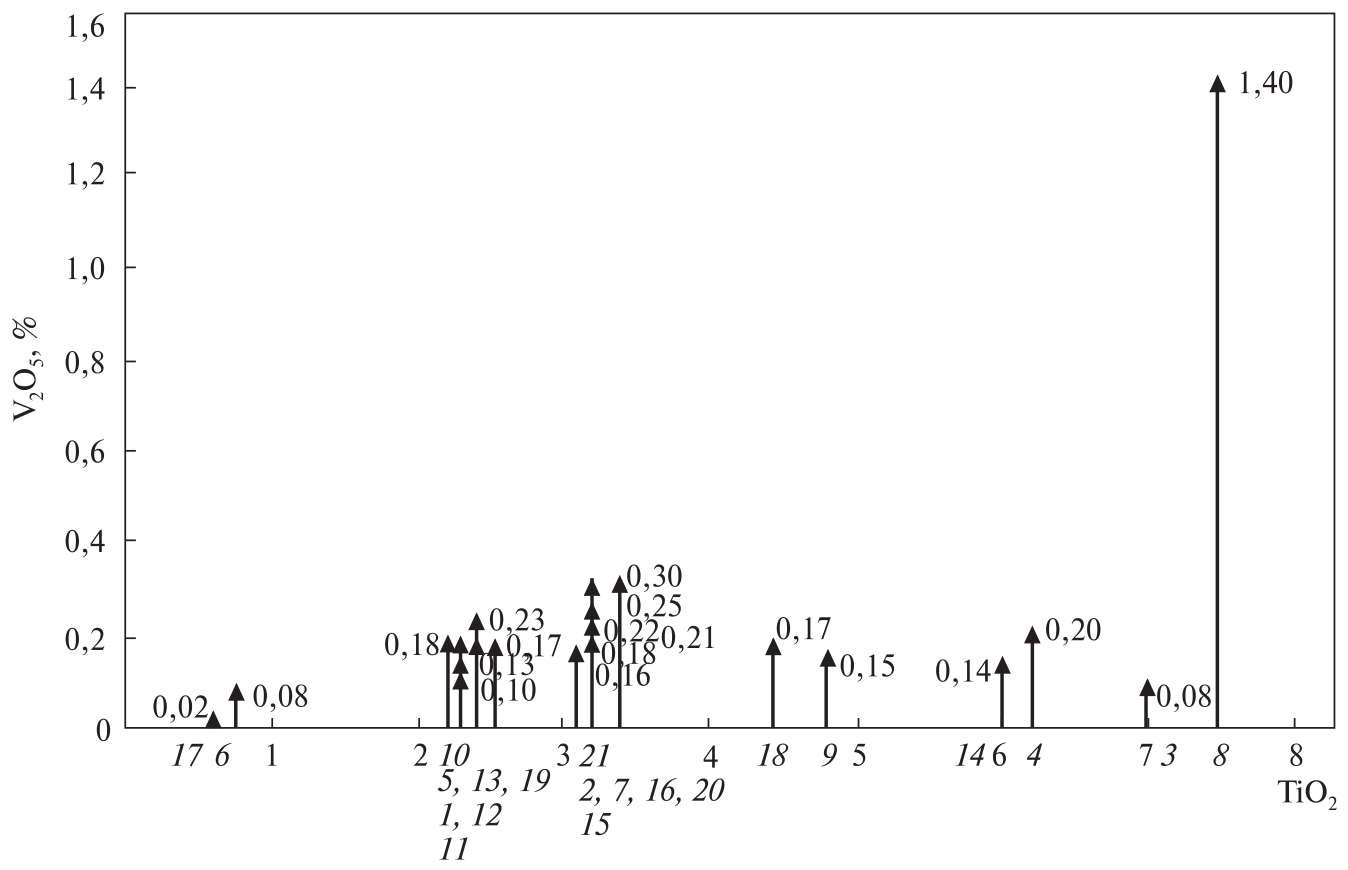

Рис. 5. Корреляция содержания $\mathrm{V}_{2} \mathrm{O}_{5}$ и $\mathrm{TiO}_{2}$ в магнетитах

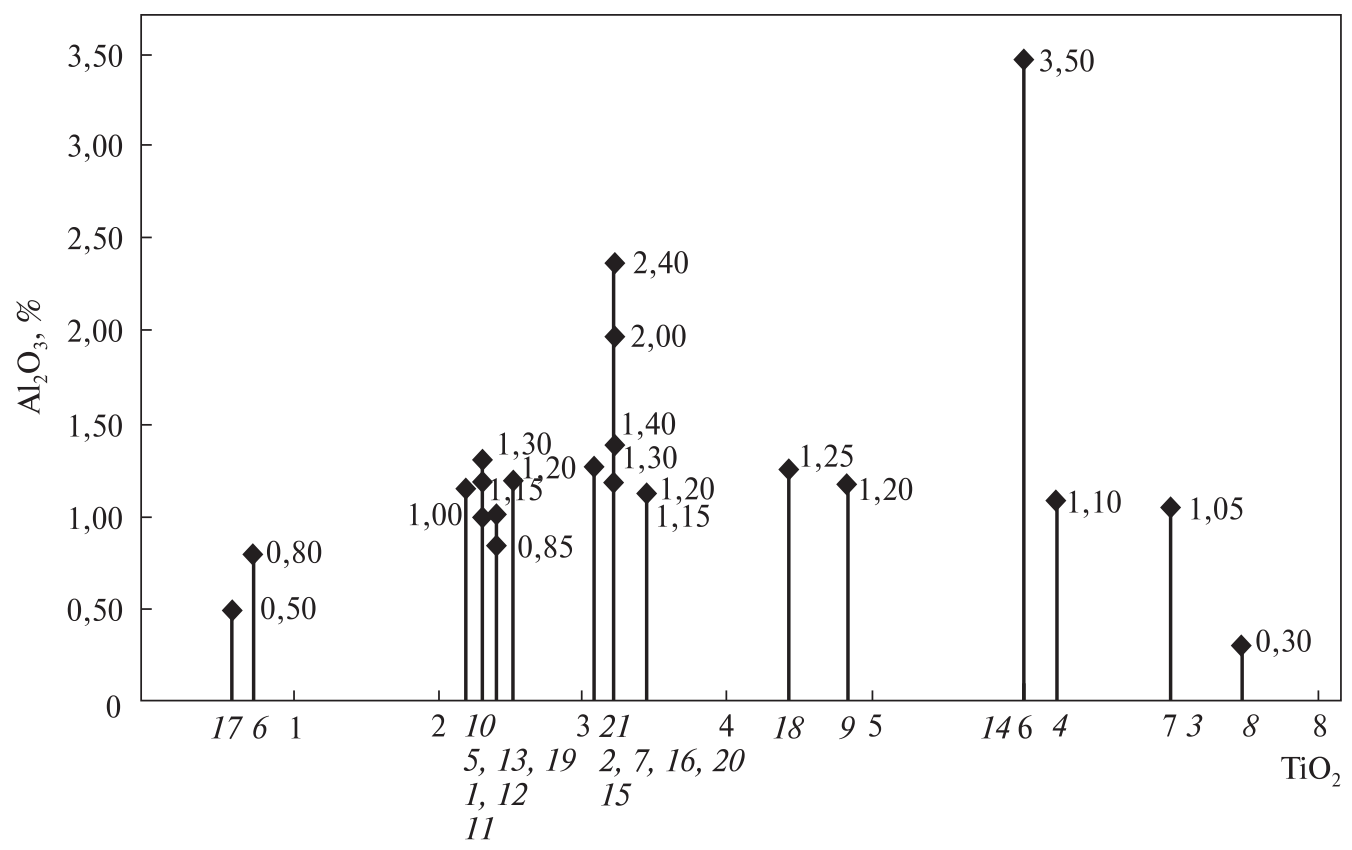

Puc. 6. Корреляция содержания $\mathrm{Al}_{2} \mathrm{O}_{3}$ и $\mathrm{TiO}_{2}$ в магнетитах

$\mathrm{Al}_{2} \mathrm{O}_{3}$ содержится в минимальном количестве $0,3 \%$ (Крым), максимальном $3,50 \%$ (Белосарайская коса) (рис. 6).

$\mathrm{SiO}_{2}$ установлен в количестве $0,25-1,80 \%$. Минимальное количество $(0,25 \%)$ приурочено к магнетиту обр. 6 острова Джарылгач, а максимальное 1,80 \% - к 


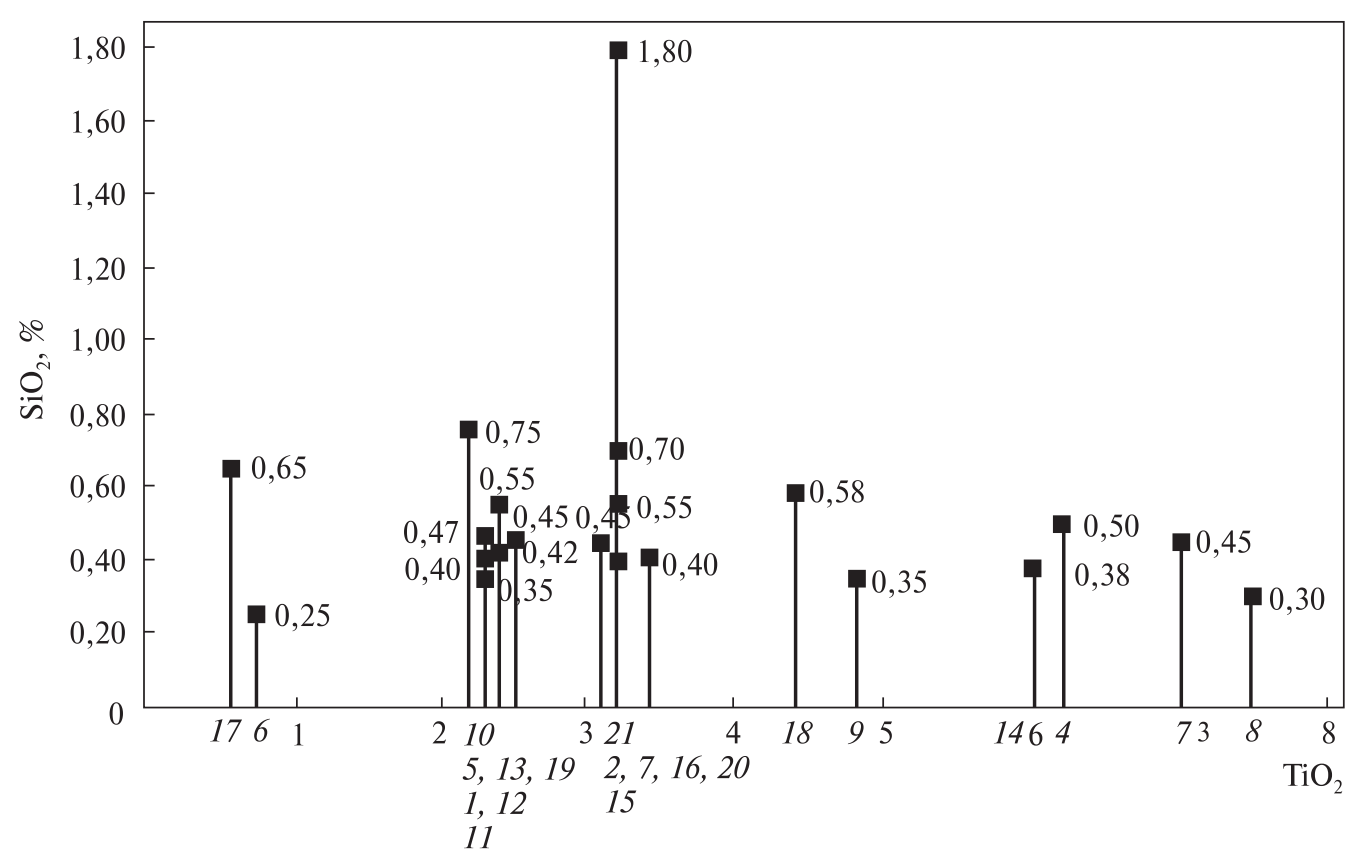

Puc. 7. Корреляция содержания $\mathrm{SiO}_{2}$ и $\mathrm{TiO}_{2}$ в магнетитах

пробе 16 (северный берег Таганрогского залива, пос. Широкино). Это содержание следует считать аномально высоким, поскольку по остальным пробам магнетита из прибрежных песков Черного и Азовского морей оно колеблется в пределах 0,3-0,70\%. При этом диапазон содержания $\mathrm{TiO}_{2}$ изменяется от 0,75\% (о. Джарылгач) до 7,5 \% (западное побережье Крымского п-ова, пос. Любимовка) (рис. 7).

Из других элементов-примесей в магнетитах из Черного и Азовского морей установлены следующие элементы (табл. 3).

$\mathrm{Ni}$ от $<0,001$ (Белосарайская коса) до 0,12 \% (коса Федотова, Темрюкский залив). $\mathrm{Nb}$ максимальных значений достигает на Белосарайской косе $(0,28 \%)$, минимальных 0,008 (о. Джарылгач). Сu от 0,12 \% (Белосарайская коса) до 0,003 (Дунай, Днестровский лиман). Zr, Co, Ag, Sc, Y, Yb - следы.

\section{Области применения магнетитсодержащих песков}

В начале XX-го века черные пески рассматривались только в качестве металлургического сырья. Анализ разрозненных, но многочисленных литературных источников позволил определить много новых областей практического применения магнитного песка. По данным Ю.А. Курникова и др. [10], магнитный песок - рыхлая осадочная порода темно-серого цвета с размером частиц 0,05-2,0 мм, в которой содержится не менее $2 \%$ зерен магнетита с подчиненным количеством других магнитных минералов.

Магнитные порошки и пески используются в магнитных системах, комплексах подготовки питьевой воды для очистки, доочистки сточных и технических вод, обработки водных систем различного назначения, когда в фильтрах используются зернистые материалы; для изготовления магнитного порошка, 
Таблица 3. Содержание примесей химических элементов в магнетите из россыпей Черного и Азовского морей (\%)

\begin{tabular}{|c|c|c|c|c|c|c|c|c|c|c|}
\hline $\begin{array}{c}\text { № табл. } \\
\text { и рис. }\end{array}$ & $\begin{array}{c}\text { № нарте } \\
\text { (рис. 1) }\end{array}$ & $\mathrm{Ni}$ & $\mathrm{Co}$ & $\mathrm{Zr}$ & $\mathrm{Nb}$ & $\mathrm{Cu}$ & $\mathrm{Ag}$ & $\mathrm{Sc}$ & $\mathrm{Y}$ & $\mathrm{Yb}$ \\
\hline 1 & $64 / 1$ & 0,025 & - & 0,02 & 0,01 & 0,003 & - & 0,001 & 0,003 & 0,001 \\
2 & $\mathrm{IV}$ & 0,035 & - & 0,01 & 0,02 & 0,012 & 0,001 & 0,001 & 0,003 & 0,003 \\
3 & 84 & $<0,001$ & - & - & 0,28 & 0,004 & 0,001 & 0,002 & 0,005 & 0,004 \\
4 & 275 & 0,020 & - & 0,03 & 0,08 & 0,003 & 0,001 & 0,003 & 0,003 & 0,002 \\
5 & $78 / 1$ & 0,020 & 0,003 & 0,02 & 0,01 & 0,018 & $<0,001$ & $<0,001$ & 0,007 & 0,001 \\
6 & $33 / 1$ & 0,010 & - & 0,02 & 0,008 & 0,004 & - & $<0,001$ & 0,005 & 0,001 \\
7 & 1 & 0,10 & - & 0,025 & 0,03 & 0,008 & 0,001 & 0,001 & 0,002 & 0,002 \\
8 & 2 & - & - & 0,1 & 0,02 & 0,002 & - & 0,002 & 0,001 & 0,001 \\
9 & 22 & 0,12 & - & 0,08 & 0,05 & 0,08 & - & 0,001 & 0,005 & 0,005 \\
10 & 35 & 0,09 & - & 0,08 & 0,01 & 0,10 & - & 0,001 & 0,005 & 0,003 \\
11 & 45 & 0,07 & - & 0,02 & 0,02 & 0,008 & - & 0,001 & 0,002 & 0,005 \\
12 & 52 & 0,06 & $\sim 0.001$ & 0,02 & 0,01 & 0,01 & - & 0,001 & 0,008 & 0.005 \\
13 & 69 & 0,09 & $\sim 0,001$ & 0,06 & 0,03 & 0,03 & - & 0,001 & 0,005 & 0,008 \\
14 & 84 & 0,04 & - & 0,08 & 0,08 & 0,12 & - & 0,001 & 0,005 & 0,002 \\
15 & 86 & 0,03 & - & 0,07 & 0,01 & 0,09 & - & 0,001 & 0,008 & 0,003 \\
16 & 104 & 0,06 & - & 0,09 & 0,01 & 0,07 & - & 0,001 & 0,006 & 0,005 \\
17 & 109 & 0,10 & - & 0,04 & $<0,01$ & 0,09 & - & - & 0,004 & 0,005 \\
18 & 128 & 0,10 & - & 0,15 & 0,04 & 0,10 & - & 0,003 & 0,006 & 0,005 \\
19 & 136 & 0,08 & - & 0,02 & 0,05 & 0,06 & - & - & 0,005 & 0,001 \\
20 & $150 / 2$ & 0,11 & - & 0,02 & 0,04 & 0,06 & - & - & 0,004 & 0,006 \\
21 & 138 & 0,12 & - & 0,06 & 0,01 & 0,05 & - & - & 0,006 & 0,005 \\
& & & & & & & & & & \\
\hline
\end{tabular}

Аналитик С.А. Козак.

П р и м е ч н и е: 1 (64/1), р. Дунай; 2 (IV), Юг Азовского моря, Арабатский залив; 3 (84), Белосарайская коса; 4 (275), Днестровский лиман; 5 (78/1), р. Дунай; 6 (33/1), о. Джарылгач; 7 (1), оз. Соленое; 8 (2), Крым; 9 (22), Коса Федотова; 10 (35), Бердянский залив; 11 (45), Коса Обиточная; 12 (52), Бердянский залив; 13 (69), Белосарайский залив, район Новопетровки; 14 (84), Белосарайская коса; 15 (86), Северный берег Таганрогского залива, район п. Широкое; 16 (104), Северный берег Таганрогского залива, район п. Широкое; 17 (109), Северный берег Таганрогского залива, корневая часть косы Беглицкой; 18 (128), Стефанидин Дар; 19 (136), р. Кубань; 20 (150/2), Бургас; 21 (138), Темрюкский залив.

применяемого в качестве наполнителя при разработке постоянных твердых и гибких магнитов, магнитной жидкости, композиционных материалов, магнитоабразивных порошков.

В древние времена на Кинбурнском п-ове и на берегу Ягорлыцкого залива северо-западной части Черного моря использовались содержащие магнетит пески, из которых выплавлялись «лучшие сорта железа» не подверженные коррозии (см. А.Г. Агбунова, 1989).

К настоящему времени ограниченное практическое применение нашли только магнитные пески на грузинском побережье Черного моря, которые используются в лечебных целях как физиотерапевтическое средство на курорте Уреки. 


\section{Выводы}

Магнетит среди минералов тяжелой фракции прибрежных отложений Азовского моря содержится повсеместно в количестве не более $1-3 \%$, а на болгарском и грузинском участках формирования пляжевых магнетитовых россыпей достигает $20 \%$ и более. Коренным источником магнетита в Северном Приазовье являются в основном габбро, сиениты, метабазиты и ультрабазиты, на Северном Кавказе - ультрабазиты. По содержанию $\mathrm{TiO}_{2}(2,2-3,4$ \%) магнетит Темрюкского залива (р-н устья Кубани) не отличается от магнетита кос Бердянской, Обиточной северного побережья Азовского моря. Магнетит ильменит-цирконовой россыпи Белосарайской косы (источник сноса - основные породы Октябрьского массива) характеризуется повышенным содержанием $\mathrm{TiO}_{2}(4,90 \%)$. С титаном парагенетически связан хром.

По данным микроспектрального анализа установлено, что наиболее высокие содержания $\mathrm{TiO}_{2}(>4$ \%) характерны для магнетитов северо-восточного побережья Азовского моря и Таганрогского залива. Эти же магнетиты обогащены $\mathrm{Cr}_{2} \mathrm{O}_{3}(>>1 \%)$, а также отличаются несколько более высоким содержанием $\mathrm{MgO}$ (до $1 \%)$, в них установлены следы ( $\approx 0,001 \%$ ) Со. В магнетитах Черного моря из кавказского и болгарского (г. Бургас) побережий содержание $\mathrm{TiO}_{2}$ установлено в количестве $2,3-3,2 \%, \mathrm{Cr}_{2} \mathrm{O}_{3}-0,45-0,9 \%$, магнетит из болгарского побережья характеризуется относительно повышенным содержанием $\mathrm{V}_{2} \mathrm{O}_{5}(0,25 \%)$, обычно в районе азовского и северочерноморского побережья магнетиты содержат этот компонент в количестве $0,10-0,20 \%$.

Полученные данные о составе примесей в магнетитах из россыпей Черного и Азовского морей свидетельствуют о том, что некоторое различие в качественном составе и количественном содержании этих примесей обусловлено различным характером пород питающих провинций.

Проведенные минералогические исследования магнетитов различных участков Азово-Черноморского бассейна показывают существенные различия в морфологическом облике минералов.

\section{СПИСОК ЛИТЕРАТУРЫ}

1. Афанасьев Г.Д. Геология магматических комплексов Северного Кавказа и основные черты связанной с ними минерализации. Тр. Ин-та геол. рудных м-ний (петрогр., минер. и геол.), вып. 20. Изд-во АН СССР, 1958.

2. Бетехтин А.Г. Минералогия. М.: Гостехиздат, 1950. 958 с.

3. Габуния К.Н. Магнитные пески Черноморского побережья. Минерал. ресурсы Грузии. Тбилиси, 1933. С. 132-137.

4. Галий С.А., Крочук В.М., Козак С.А. Генетические особенности магнетита из карбонатитов Украинского щита. Минерал. журнал. 1982. № 2. С. 85-89.

5. Джанджгава К.И., Яшвили Г.Е. Инженерно-геологические условия шельфа Южной Колхиды в связи с проблемой подводной добычи магнетитовых песков. Проблемы гидрогеологии и инженерной геологии. Тбилиси, 1977. С. 140-146.

6. Димитров П.С., Новикова 3.Т. История развития осадочного комплекса в четвертичное время и условия формирования скоплений тяжелых минералов на шельфе. Геол.-геофиз. исследования болгарского сектора Черного моря. София: Изд-во БАН, 1984. 318 с.

7. Елисеев Н.А., Кушев В.Г., Виноградов Д.П. Протерозойский интрузивный комплекс Восточного Приазовья. М.-Л.: Наука, 1965. 204 с. 
8. Иноземцев Ю.И. Литолого-минералогические особенности прибрежно-морских осадков Азовского моря: Препринт ИГФМ АН УССР. Киев, 1974. 57 с.

9. Козак С.О., Олексенко С.П., Галій С.А., Щербаков І.Б. Мікроспектральний аналіз магнетитів. Доп. АН УРСР, Сер. Б. 1980. № 10. С. 17-19.

10. Курников Ю.А., Кравченко С.Н., Орлюк М.И. Магнитный песок: новый взгляд на перспективы практического использования. Геол. и полезн. ископаемые Мирового океана. 2005. № 2. C. $111-120$.

11. Ляхович В.В. Акцессорные минералы. М.: Наука, 1968. 275 с.

12. Минералогия Приазовья / Лазаренко Е.К., Лавриненко Л.Ф., Бучинская Н.И., и др. К.: Наук. думка, 1980. 432 с.

13. Спиридонов Э.М., Коротаева Н.Н., Ладыгин В.М. Хромшпинелиды, титаномагнетит и ильменит островодужных вулканитов Горного Крыма. Вести. МГУ. Сер. геол. 1989. № 6. C. $37-55$.

14. Твалчрелидзе Г.А. Эндогенная металлогения Грузии. М.: Госгеолтехиздат, 1961. 344 с.

15. Цымбал С.Н., Полканов Ю.А. Минералогия титано-циркониевых россыпей Украины. К.: Наук. думка, 1975. 247 с.

16. Цветкова-Голева В. Тяжки минерали в пясъците от южното българско крайбережие. Изв. Геол. ин-та БАН. Сер. рудн. и их изучение. Т. 23. 1975. С. 77-81.

17. Чернышева Л.В. Типоморфные особенности магнетитов магматических, карбонатитовых и скарновых месторождений. Автореферат дисс. ... кандидата геолого-минералогических наук. Москва, 1974. 30 с.

18. Шило Н.А. Основы учения о россыпях. М.: Наука, 1981. 383 с.

19. Шнюков Е.Ф., Зиборов А.П. Минеральные богатства Черного моря. К.: Карбон-Лтд, 2004. $278 \mathrm{c}$.

20. Шнюков Е.Ф., Соболевский Ю.В., Григорьев А.В. Роль погребенных аллювиальных толщ в формировании магнетитовых россыпей Болгарии. Литолого-геохимические условия формирования донных отложений. К.: Наук. думка, 1997. С. 56-64.

21. Шнюков Е.Ф., Щербаков И.Б., Шнюкова Е.Е. Палеоостровная дуга севера Черного моря. К.: Агентство «Чернобыльинтеринформ», 1997. 287 с.

22. Юрк Ю.Ю., Кашкаров И.Ф., Полканов Ю.А. и др. Алмазы песчаных отложений Украины. К.: Наук. думка, 1973. 163 с.

Статья поступила 20.02.2019

\section{Ю.І. Іноземцев, О.О. Паришев, З.В. Красножина, М.О. Маслаков}

\section{МАГНЕТИТ $З$ ПРИБЕРЕЖНО-МОРСЬКИХ РОЗСИПІВ ЧОРНОГО І АЗОВСЬКОГО МОРІВ}

У статті містяться відомості про характер розподілу і мінеральний склад сучасних прибережно-морських розсипів Чорного і Азовського морів. Виділено такі основні типи розсипів: ільменіт-рутил-цирконові, іноді з домішкою монациту; магнетит-титаномагнетитові з цирконом і ільменітом; гранатово-магнетитові та магнетитові. Наведені результати мінералого-геохімічних досліджень магнетитів з головних розсипів і розсипепроявів.

Ключові слова: Чорне, Азовське моря, прибережно-морські розсипи, магнетит.

\section{Yu.I. Inozemtcev, O.O. Paryshev, Z.V. Krasnozhyna, M.O. Maslakov}

\section{MAGNETITE FROM COASTAL DEPOZITS OF BLACK AND AZOV SEAS}

The article contains information about the nature of distribution and the mineral composition of modern coastal-marine deposits of the Black Sea and Sea of Azov. The following main types of placers are distinguished: ilmenite-rutile-zircon, sometimes with a mixture of monazite; magnetitetitanomagnetite with zircon and ilmenite; garnet-magnetite and magnetite. The results of mineralogical and geochemical studies of magnetites from major placers and placer occurrences are presented.

Keywords: Black Sea, Sea of Azov, offshore-marine mineral deposits, magnetite. 